\title{
De las urnas a la movilización popular. Elecciones presidenciales de 1970 en Colombia
}

\author{
From the Polls to Popular Mobilization. \\ The 1970 Presidential Elections in Colombia
}

\author{
Olga Yanet Acuña Rodríguez \\ Universidad Pedagógica y Tecnológica de Colombia, Colombia | olga.acuna@uptc.edu.co
}

\begin{abstract}
Resumen
El texto resalta cómo el inconformismo de los sectores populares con el tradicionalismo político, liberal-conservador en Colombia y con las irregularidades en el conteo y reconteo de los votos en las elecciones presidenciales de 1970, puso en crisis al régimen político "frentenacionalista", y a su candidato Misael Pastrana Borrero. Desde la historia política y social se analiza el papel de las masas y las posiciones y acciones de las elites para legitimar el poder; así, el evidente fraude electoral en las elecciones del 19 de abril de 1970 fue asumido por las masas como una burla al sistema democrático y a su expresión como ciudadanos, lo que motivó movilizaciones en diversas regiones del país. A partir de este hecho los actores sociales reivindicaron su papel como ciudadanos y reclamaron sus derechos, acudiendo a la denuncia en las diversas instituciones, a la movilización y a la protesta y, tres años después, a la movilización armada que se denominó M-19.
\end{abstract}

Palabras clave: elecciones; fraude; poder; movilizaciones populares; guerrilla M-19.

\section{Abstract}

The text shows how the popular sectors' dissatisfaction with liberal-conservative political traditionalism in Colombia and irregularities in the vote counting and recounting in the 1970 presidential elections created a crisis for the "National Front" political regime and its candidate Misael Pastrana Borrero. Political and social history is used to analyze the role of the masses and the positions and actions of the elites to legitimize power. The blatant electoral fraud in the April 19, 1970 elections was regarded by the masses as a travesty of the democratic system and of their expression as citizens, prompting demonstrations in various parts of the country. As a result of this event, social actors claimed their role as citizens and demanded their rights, filing complaints with various institutions and engaging in mobilization and protest and, three years later, the armed movement that came to be called M-19.

Key words: elections; fraud; power; popular movements; M-19 guerrilla movement.

Fecha de recepción: 26 de enero de 2015 Fecha de aceptación: 15 de junio de 2015

Secuencia, ISSN 0186-0348, núm. 96 | septiembre-diciembre de 2016 | pp. 193-225

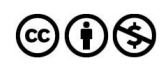




\title{
De las urnas a la movilización popular. Elecciones presidenciales de 1970 en Colombia
}

\author{
Olga Yanet Acuña Rodríguez
}

$\mathrm{E}$ 19 de abril de 1970 en Colombia se llevaron a cabo las elecciones presidenciales y para corporaciones públicas; en estos comicios se disputaban el poder dos tendencias: el tradicionalismo político liberal-conservador articulado en un movimiento de coalición denominado Frente Nacional, ${ }^{1}$ y un movimiento popular emergente denominado Alianza Nacional Popular (ANAPO) que pretendía agrupar disidentes del liberalismo, del conservadurismo y de los sectores populares. En la campaña electoral se pudo apreciar el crecimiento del movimiento de masas encabezado por el ex dictador Gustavo Rojas Pinilla, en oposición a las elites políticas, de los sectores económicos y voceros de los medios de comunicación que apoyaban la candidatura de Misael Pastrana Borrero. En los resultados electorales hubo ambivalencias y demoras en la publicación de los resultados. Inicialmente los medios de comunicación anunciaron a Rojas Pinilla como ganador de las elecciones y, minutos más tarde, los comunicados de la Registraduría -el organismo electoral colombiano-, le daban la mayoría al candidato oficialista Misael Pastrana Borrero. La manipulación de los resultados electorales fue cuestionada por los seguidores de la ANAPO por lo que denunciaron fraude y corrupción por parte del gobierno, realizaron manifestaciones en diversas regiones del país, y tres años después surgió un movimiento armado denominado M-19, que reclamaba paz, justicia y respeto por la voluntad popular. Este movimiento armado llegó a ser la guerrilla urbana más importante del país, sólo comparable con los "Tupamaros" de Uruguay.

En un Estado democrático las elecciones se consideran el principal mecanismo de participación política gracias a las cuales, teóricamente, el votante influye en la distribución del poder del Estado y delega esta función en los

1 El Frente Nacional en Colombia fue un acuerdo político entre las elites del partido liberal y del conservador, que desde 1958 se turnaban la administración del Estado por periodos de cuatro años, hasta 1974.

\section{()ㅜ(1) $\$$}


líderes políticos o caudillos que aspiran a obtener el poder político, partiendo de la consecución del mayor número de sufragios a su favor. El análisis se fundamenta en la relación entre poder y legitimidad, a partir de los planteamientos de Max Weber (1944). Si bien el poder puede estar asociado a la coacción, a la violencia o a la convicción de su legitimidad, el poder es una probabilidad para imponer la propia voluntad dentro de una relación social, mientras que la dominación se refiere a la probabilidad de obtener obediencia a un mandato (p. 43). Weber establece tres tipos de dominación legítima: de carácter racional, es decir que su fundamento descansa en la creencia en la legalidad de órdenes estatuidas para ejercer los derechos de mando. El segundo se refiere a la autoridad tradicional o patriarcal basada en principios tradicionales como la autoridad ejercida por el príncipe o el patriarca; la tradición es reconocida como fundamento central para ejercer la autoridad. El tercer tipo de dominación legítima se refiere al carácter carismático, que descansa en el reconocimiento de un don o gracia personal, por vocación, por devoción, por heroísmo, y demás cualidades personales que potencializan al caudillo (Weber, 1944, pp. 1056-1057).

En relación con el establecimiento de la democracia formal en un sistema político, Guy Hermet (citado por Gómez, 1986, p. 128) aporta tres criterios para establecer el tipo de democracia: la libertad del elector, en el sentido de que este ejerza su derecho al voto sin presiones ni represalias; que su voto no sea fragmentado en categorías o cuerpos electorales que anulen la idea de soberanía popular, y que la papeleta sea computada de manera no fraudulenta, incluso cuando el voto emitido no corresponda a los deseos del gobierno en turno. Según Hermet, "la falsificación de las elecciones niega, de hecho, la libertad del votante" (citado por Gómez, 1986, p. 128). Es en este sentido que la emisión del voto genera espacios de participación política, produciéndose así una relación entre las instituciones y los electores para definir el poder.

Otra de las características de la democracia formal es la competitividad, asociada al pluralismo político. Según Nohlen (1995, p. 12), en un sistema democrático habría competitividad si el elector tiene más de dos opciones para poder elegir, si puede decidir libremente y si su decisión está amparada por la ley. El tercer aspecto de la democracia formal tiene que ver con lo que se decide en el proceso electoral, lo que está en juego en las elecciones, es decir, si el voto incide en la decisión del poder, el papel del escrutinio en la definición del poder (Gómez, 1986, p. 128). Según Hermet (citado por Gómez, 1986), si en alguno de estos tres aspectos hay acciones fraudulentas, se aprovecha la maquinaria legal para incidir en el proceso electoral, incluso para cambiar el

\section{(이요}


rumbo de una elección que creen no ser capaces de ganar (Lehoucq, 2007, p. 4); puede invalidarse el proceso democrático, bien por falta de libertad del votante, por las desventajas en la competitividad, o por la adulteración en los resultados electorales.

El objetivo de este texto es analizar las manifestaciones de inconformismo de los diversos sectores sociales, relacionadas con el empoderamiento de las elites políticas tradicionales a través de las familias: Ospina, Lleras, Valencia, Pastrana, en la administración de las instituciones del Estado, bajo la figura de la coalición política frentenacionalista. El detonante fue el fraude en los comicios presidenciales, efectuados el 19 de abril de 1970, lo que suscitó denuncias sobre prácticas de corrupción y coacción que deslegitimaban la participación popular; fueron principalmente los seguidores de la ANAPO quienes expresaron el inconformismo por el fraude electoral a través de comunicados, movilizaciones, confrontaciones violentas $y$, tres años después, con la conformación de un grupo armado denominado M-19 que, además de defender la democracia, pretendía realizar la revolución socialista, bajo una perspectiva nacionalista y antiimperialista que no era ajena a otras pretensiones de la izquierda Latinoamericana.

Es de resaltar que estas acciones son una muestra del grado de conflictividad en el sistema político colombiano (Pozzi y Pérez, 2011, p. XIII), que no es ajeno a los procesos latinoamericanos vividos a partir de la década de los años sesenta en que las nuevas generaciones -bajo pretensiones de cambio-, plantearon proyectos de revolución social, de donde se desprendió la consolidación de grupos guerrilleros, político-militares y de defensa de la democracia. Desde esta perspectiva se asumió que la violencia, la movilización social y las elecciones eran hechos sociales vinculados a la política, a la economía, a las representaciones colectivas y a los imaginarios sociales (González, 2003, p 12). Tal vez la izquierda más radical de ese momento, vinculada con los movimientos sociales, asumió que la movilización armada era un camino para conquistar el poder y construir un nuevo orden social con el protagonismo de los sectores populares (Pozzi y Pérez, 2011, p. XIV).

El texto está estructurado en cinco apartes, a través de los cuales se pretende explicar el proceso político experimentado por la sociedad colombiana en las elecciones presidenciales de 1970. Así, en la primera parte se plantean las principales tesis sobre el fraude electoral de 1970 y el surgimiento de la guerrilla urbana denominada Movimiento 19 de Abril, nombre asumido en memoria al fraude electoral. En la segunda se abordan los aspectos que contribuyeron a generar identidad con los candidatos presidenciales, cuando se

\section{()(1) $(9$}


pusieron en juego las nociones de continuidad y cambio y se pretendió articular al mayor número de votantes. La tercera parte hace alusión al manejo de la opinión pública a partir de la publicación de los resultados electorales y de las reacciones generadas en los seguidores de la Alianza Nacional Popular y la acción del gobierno en la legitimación de los resultados electorales. En el cuarto apartado se hace alusión a las manifestaciones de los seguidores de la ANAPO en acción de protesta por el fraude en los resultados electorales y se describen las movilizaciones realizadas en varias regiones del país. Finalmente en el último apartado se da cuenta de la proyección del movimiento anapista en dos direcciones: como partido político y como movimiento armado que pretendía denunciar las irregularidades del sistema democrático y la consolidación de un movimiento insurreccional de masas, con miras a lograr la revolución socialista.

\section{LAS ELECCIONES DE 1970 VISTAS POR LA HISTORIOGRAFÍA}

El tema de la historia electoral sigue siendo un campo muy importante para la historiografía colombiana, que ha centrado el interés de algunos historiadores para tratar de comprender cómo las elecciones fueron un medio de legitimidad y representación en la perspectiva de construcción de la nación (Annino, 1995; Bushnell, 1994; Malamud, 2000; Posada, 2000, 2003), y formas de construcción de ciudadanía (Acuña, 2010); recientemente se han hecho análisis sobre las elecciones para comprender la expresión de la política en el entorno local y regional, el juego político y los intereses que se desligan de las prácticas (Ternavasio, 2002). Estos trabajos han sido inspirados por las producciones historiográficas realizadas para comprender la formación de ciudadanía en Europa y América Latina, especialmente durante el siglo XIX, pero que hacen aportes sustanciales frente a la inserción de los sectores populares en la vida política, y en cómo estos asumen la participación y representatividad (Irurozqui, 2000; Sábato, 1998).

Las elecciones presidenciales de 1970 en Colombia se han convertido en un mito; los electores las recuerdan y las asocian con uno de los mayores fraudes en la historia electoral colombiana. Al respecto el texto El populismo atrapado, la memoria y el miedo. El caso de las elecciones de 1970 (Ayala, 2006), hace alusión a la campaña electoral, analizando la plaza pública, la tensión política y social, el espectáculo de las movilizaciones y el uso de los medios

\section{(이요}


de comunicación. Asimismo se refiere al manejo de la opinión pública, en relación con la ambivalencia de los resultados electorales del 19 de abril de 1970, por parte de los líderes frentenacionalistas. Respecto a las movilizaciones el texto describe las concentraciones, la euforia y las acciones de protesta que se generaron en diversas regiones del país. En este libro César Ayala centra su atención en la ANAPO como movimiento político de masas en oposición al tradicionalismo liberal-conservador, articulado en la coalición denominada Frente Nacional. Aunque el autor hace una amplia descripción del fenómeno anapista y de las implicaciones políticas, no logra explicar cómo la movilización de las masas implicó un cambio en la mentalidad política de los sectores populares y una forma de resistencia al tradicionalismo político; es importante señalar que el auge electoral de la ANAPO significó una transformación en la estructura política del país y en la subjetividad política del elector.

Sobre el origen de la ANAPO, igualmente César Ayala (2005) lanza algunas hipótesis sobre el surgimiento de este movimiento político y señala que su consolidación es el conservadurismo, lo que generó en su interior tendencias políticas diversas que oscilaban entre la extrema izquierda y la extrema derecha, sin desconocer la posición de seguidores del liberalismo y del conservadurismo que deseaban cambios profundos en la organización social. Sin embargo, sus reflexiones en ocasiones parecen una apología a Rojas Pinilla y a la ANAPO como movimiento político, porque considera que "gracias" a Rojas todas las personas podían sentirse incluidas y representadas. Finalmente hace una comparación de los hechos ocurridos el 9 de abril de 1948 y el 19 de abril de 1970 en Colombia, y concluye que estos momentos históricos no contaron con una organización y dirección que lograran generar cambios sustanciales para el pueblo. Igualmente se omite el análisis sobre la falta de legitimidad del gobierno y la respuesta de los actores sociales.

Por su parte, el texto La Alianza Nacional Popular (ANAPo) en Santander 1962- 1976 (Báez, 2006, p. 109) describe el proceso político de surgimiento y crecimiento de la ANAPo en Santander, las estrategias de articulación de las masas y las controversias con las elites políticas regionales y nacionales. Adriana Báez -a diferencia de César Ayala- resalta el papel político de las elites regionales y la forma de articulación de las masas. Y en relación con las elecciones de 1970, Báez se refiere a la posición del gobierno y a la reacción de los líderes, militantes y seguidores de la ANAPO; en forma detallada permite apreciar el desarrollo de las movilizaciones, los antagonismos y las instrucciones impartidas a las masas movilizadas en defensa del triunfo de Rojas Pinilla. Señala la autora que una vez consumado el fraude se consolidó

\section{()(1) $(3$}


la ANAPO socialista, que se convertiría en la base del movimiento armado 19 de Abril o guerrilla urbana, conformado en 1973 en señal de protesta por la corrupción y manipulación de las elites políticas en las elecciones. Este resulta ser un planteamiento interesante que no se profundiza al interior del texto y sugiere un campo de estudio interesante para comprender el desgaste del poder que tuvieron las elites tradicionales en las regiones, lo que justificó la emergencia de otras opciones políticas.

La continuidad de la ANAPO y su articulación con el M-19 ha generado posiciones encontradas. Por ejemplo, el texto "La ambivalente relación entre el M-19 y la ANAPo" establece un vínculo entre la ANAPo, fundada en 1961 por el General Gustavo Rojas Pinilla, y la creación del Movimiento 19 de Abril, como guerrilla urbana colombiana, lanzada en 1974. El autor parte de una reflexión sobre la exclusión de los diversos actores políticos generada durante el pacto político Frente Nacional 1958-1974; por ende, la ANAPO se convirtió en un cuerpo político que agrupó a todos los sectores excluidos del sistema: derechistas, izquierdistas y demócratas, articulados bajo una connotación de nacionalismo; así inició el debate electoral de 1970 (León, 2012, pp. 239259). Este texto aporta elementos sustanciales que permiten ver la relación del movimiento armado y del movimiento de masas, las concepciones socialistas y nacionalistas en disputa, como fundamento del proyecto político militar, lo que generó acercamientos y controversias. El texto es bastante sugerente puesto que permite ver la relación entre las dos tendencias, con lo que pone en entredicho la tesis de que el M-19 sea la continuidad de la ANAPO; por el contrario, uno de los mayores aportes está en la comprensión del contexto político nacional y en la incidencia de ideas socialistas que afianzan las pretensiones de la izquierda en el sentido de realizar la revolución socialista.

Por su parte, Ginneth Narváez (2012) hace un estudio sobre las tácticas y estrategias utilizadas por la guerrilla del M-19. Resalta cómo esta guerrilla introdujo dos elementos sustanciales como parte de su estrategia político-militar; se refiere a la milicia urbana y a la técnica del foquismo. El texto parte de una revisión historiográfica sobre los estudios centrados en el M-19 y de sus principales aportes; posteriormente se centra en el contexto, en la guerra insurgente y en las tácticas. Sin embargo, su estudio no permite apreciar una secuencia de la organización y desarrollo del M-19 como grupo insurgente. Son muchas las preguntas que nos surgen sobre el origen y su articulación con el movimiento anapista; simplemente se limita a señalar que muchos de sus líderes militaron en la guerrilla de las FARC y que establecieron una experiencia militar y política. Pero no se perciben explicacio-

\section{()(1) $(9$}


nes puntuales que permitan al lector establecer conexiones, interrelaciones, especialmente en lo político y en su articulación con las masas. En términos generales este trabajo hace aportes sustanciales sobre el significado del M-19 como guerrilla, pero no con una perspectiva política, de movilización de masas ni con una pretensión de toma del poder, tanto con las armas como con la instrumentalización de los procesos políticos.

El texto de Mario Luna Benítez (2006), "El M-19 en el contexto de las guerrillas colombianas", desde una perspectiva sociológica y bajo el modelo de Eduardo Pizarro Leongómez, hace un análisis interesante sobre el contexto, la diferencia y las particularidades de las guerrillas en Colombia; señala que el M-19 planteó cambios sustanciales en la forma de lucha, en la organización y en la concepción política. Sin embargo, el título es llamativo pues pareciera que hay mayor desarrollo sobre el papel político y militar del M-19, pero a lo largo de su contenido se encuentran pequeñas descripciones y finalmente culmina con una página de alusiones al M-19 cuando ha sido parte del objeto planteado. Aunque la argumentación teórica es interesante, deja vacíos sustanciales sobre el surgimiento del M-19 y de su articulación con la ANAPO.

La pregunta central que se plantean estos autores tiene que ver con el surgimiento de la ANAPO y la forma como fue ganando posiciones electorales tanto en las grandes ciudades como en las regiones y localidades (Ayala, 2005; Báez, 2006), lo que lleva a plantear que la AnApo fue efectivamente una opción política al Frente Nacional, que logró capturar la atención popular, posiblemente por la perspectiva carismática de Rojas Pinilla y por su discurso populista, pero igualmente ligado a personajes como Ignacio Vives y el padre Garcés, líderes de gran trayectoria política que rechazaban la continuidad del acuerdo político. Por su parte León Palacios (2012) -además de considerar a la ANAPO como un proyecto político-, también analiza su estructura, los alcances y los proyectos estableciendo dos tendencias llamadas por él de derecha y de izquierda. Esta reflexión es interesante para este artículo porque permite apreciar las tendencias políticas al interior de la ANAPo y los posibles vínculos que marcan tendencias radicales hasta el surgimiento del movimiento armado M-19. A pesar de que los autores han hecho un estudio sustancial sobre las elecciones de 1970, no han considerado la relación entre poder y legitimidad como perspectiva de interpretación, lo que nos permitirá ver cómo los resultados electorales cuestionados por las masas fueron legitimados racionalmente por las autoridades gubernamentales, a la vez que inspiraron diversas formas de pronunciamiento por parte de los electores que sintieron vulnerados sus derechos.

\section{(ㅇ)(1) $(3$}


El desarrollo de las elecciones en Colombia, si bien ha sido una expresión de la ciudadanía política, en sus prácticas se ha podido apreciar la mezcla de lo legal y lo ilegal, la instrumentalización de las instituciones del Estado para satisfacer los intereses de los grupos que ostentan el poder; de esta manera se ha legitimado la presencia de hegemonías políticas que han gobernado el país en ciertos periodos. Por ejemplo: la experiencia federal de 1863 a 1886; la república conservadora de 1886 a 1930; la hegemonía liberal de 1930 a 1946; la hegemonía conservadora de 1946 a 1953; el Frente Nacional de 1958 a 1974. Durante estos periodos, las elecciones fueron el medio sustancial para acceder y conservar el poder, pero los partidos -tanto el ganador como el perdedor- acudieron a prácticas de fraude, presión y violencia para afianzar el poder.

Otro momento de la historia política colombiana lo constituye el gobierno militar de Gustavo Rojas Pinilla entre 1953 y 1957; durante este lapso se vieron amenazadas las libertades civiles, puesto que el mandatario además de controlar la opinión pública con las manifestaciones y con la expresión, decidió censurar los periódicos, las emisoras de radio y clausurar aquellos medios que se declaraban en oposición al régimen; por otra parte, estableció un programa con sentido social con el fin de bajar el costo de vida y atraer la atención de los sectores más vulnerables. De esta manera, construyó una base política muy sólida apoyada por los sectores populares que esperaban un cambio sustancial en las condiciones de vida; la otra tendencia de oposición la conformaban los dirigentes políticos de los partidos tradicionales liberal-conservador, que justamente decidieron consolidar una coalición denominada Frente Nacional, para ponerle fin al gobierno militar de Gustavo Rojas Pinilla en 1957.

La salida de Rojas Pinilla de la presidencia lo motivó a consolidar un movimiento político para regresar al poder por la vía electoral; así inició una amplia movilización con apoyo popular el 23 de abril de 1961 (Ayala, 2005) con la consigna "Paz y justicia social", bajo la denominación de la ANAPo que cada vez tenía mayor número de seguidores que se aglutinaban en las plazas públicas para escuchar los discursos y arengas del caudillo-líder carismático (Weber, 2000, p. 5).

El fortalecimiento electoral del movimiento anapista se pudo apreciar en el incremento del número de sufragios a su favor, y en el número de concejales, diputados, representantes y senadores, lo que le dio un potencial electoral en los comicios de 1970. Así, durante más de tres meses de campaña electoral estas coaliciones pretendieron fijar en la mente de los electores la

\section{(1)(1) $\$$}


disidencia, a partir de relaciones políticas como "democracia y dictadura", y desde una connotación social la relación entre "oligarquías y el pueblo", lo que en términos generales replanteó las identidades partidistas y recreó el sentido social y político del elector.

\section{MISAEL PASTRANA Y GUSTAVO ROJAS EN LA NEBULOSA ELECTORAL: ENTRE GABELAS Y MOVILIZACIÓN DE MASAS}

El proceso electoral de 1970 se inició en un contexto de crisis política y social en Colombia, entre estos: movimientos sociales, cierre de las universidades, movilización de estudiantes tanto de universidades públicas como privadas, paro y movilización de profesores de los colegios que reclamaban la renuncia del ministro de Educación; mientras tanto, campesinos y obreros preparaban el llamado "Paro Patriótico". ${ }^{2}$ En ese contexto emergen cuatro candidatos de tendencia conservadora: Misael Pastrana Borrer, ${ }^{3}$ en representación del oficialismo frentenacionalista, candidato de las elites liberales y conservadoras unidas; el ex general Gustavo Rojas Pinilla, ${ }^{4}$ de ascendencia conservadora y con una perspectiva política nacionalista, en nombre de la Alianza Nacional Popular, movimiento político fundado por disidentes del liberalismo y del conservadurismo, por sectores de izquierda y simpatizantes del gobierno militar de Gustavo Rojas; Belisario Betancourt, conservador del departamento de Antioquia, crítico del Frente Nacional y con una propuesta de gobierno social-cristiano, y Evaristo Sourdís, conservador de la Costa Atlántica, con un sentido social, cuyo programa de gobierno se enfocó a reivindicar la autonomía de las regiones. Estas elecciones, bajo los preceptos de democracia formal, lograban la competitividad (Gómez, 1986, p. 128), puesto que el elector tenía cuatro opciones para tomar una decisión.

Las particularidades del discurso electoral tienen que ver con el uso de las contradicciones, a través de las cuales se construyó la imagen del héroe y el villano que caracterizaron el desarrollo de la campaña electoral en 1970. Por ejemplo: el candidato oficialista, Misael Pastrana, hizo alusión al dilema

${ }^{2}$ El Espectador, 3 de marzo de 1970.

3 Designado el 6 de diciembre de 1969 por Mariano Ospina Pérez.

${ }^{4}$ El Espectador, 1 de marzo de 1970.

\section{(이요 $(3$}


"cambio social o violencia", refiriéndose a su candidatura y a la de su opositor Gustavo Rojas Pinilla, mientras centró su programa de gobierno en el desarrollo económico, la industrialización y la tecnologización. Por su parte, el candidato de la ANAPO en su programa de gobierno reivindicó las políticas sociales, el mejoramiento de las condiciones de vida para los sectores populares, como se puede apreciar en un fragmento de su discurso: "Yo en cambio, abogo por un desarrollo armónico y ordenado de Colombia, pero sin olvidar que ese progreso no puede alcanzarse asfixiando de impuestos y con medidas que encareciendo los costos de la vida llevan hambre y miseria a millones de compatriotas." 6

En esta campaña electoral hubo una fuerte intervención del gobierno con el apoyo al candidato oficialista, Misael Pastrana. Tanto el presidente Carlos Lleras Restrepo, como el alcalde de Bogotá Virgilio Barco, inauguraron permanentemente obras públicas, instituciones e hicieron alusión a las obras realizadas durante el gobierno del Frente Nacional desde 1958; con estas alusiones se pretendió hacer ver que el país había logrado desarrollo y modernización durante este periodo, lo que justificaba su continuidad. Por otra parte -a pesar de la prohibición de que los funcionarios públicos participaran en política- durante el periodo preelectoral aparecieron varias publicaciones en las cuales figuraba el presidente inaugurando obras. ${ }^{7}$

Justamente el día de la inscripción de la candidatura de Misael Pastrana, el 10 de abril, se inauguraron los talleres-carpas. En las alocuciones de Carlos Lleras como presidente, se refirió a la defensa de la democracia, por lo que se justificaba apoyar la candidatura de Pastrana, mientras públicamente rechazó el regreso de Rojas al poder al que se refirió como la dictadura. ${ }^{8}$ Gran parte de la campaña electoral de Misael Pastrana la hicieron el presidente Lleras y su comitiva, sumados a la acción de la prensa y de las instituciones del Estado, que fueron utilizadas como medios de dominación (Weber, 1944, p. 1056) con el fin de influir en la decisión de los electores.

Los periódicos publicaron fotografías de Rojas Pinilla sobre los hechos más polémicos de su gobierno: la muerte de los estudiantes, la censura de la

${ }^{5}$ El Espectador, 4 de marzo de 1970.

${ }^{6}$ Gustavo Rojas Pinilla. Comunicado número 4, sobre el memorándum enviado a los candidatos presidenciales por el doctor Carlos Lleras Restrepo, presidente de la república, 30 de abril de 1970. Presidencia de la República. Secretaría Privada. Caja 89, carpeta 1. Archivo General de la Nación (AGN), Colombia.

${ }^{7}$ El Espectador, 6 de marzo y 5 de abril de 1970.

${ }^{8}$ El Espectador, 8, 9, 15 de marzo de 1970 y 7 de abril de 1970.

\section{()ㅜ(1) $\$$}


prensa, el estado de sitio y el debilitamiento del sistema democrático; lo que hasta ese momento justificaba la no elección de Rojas porque ponía en peligro la democracia. La prensa nacional fue uno de los principales opositores de la elección de Rojas y con sus reportajes, fotografías y editoriales, pretendieron influir como actor político en la opinión pública.

Por su parte, Rojas Pinilla acudió al reconocimiento popular, acercándose a la legitimidad carismática del caudillo (Weber, 2000, pp. 5-6); durante su campaña hizo fuertes críticas al modelo económico del Frente Nacional y al abandono en que el gobierno tenía a los sectores populares, así como a las políticas sobre educación, salud y bienestar social que eran los pilares de su programa de gobierno. Resaltó la participación tanto de liberales como de conservadores en la administración pública, y puso énfasis en la capacidad de los funcionarios para ejercer los cargos.

Paradójicamente a las prácticas dictatoriales implementadas durante su gobierno en 1953-1957, Rojas planteó -como parte de su programa de gobierno- garantizar las libertades, los derechos y la igualdad de oportunidades para trabajar al servicio del Estado. Propuso la elección popular de gobernadores, intendentes, comisarios, alcaldes, jueces y agentes del ministerio público con el fin de garantizar la eficacia en la administración pública. Tal vez una de las mayores preocupaciones fue cómo bajar el costo de vida, para lo cual planteó disminuir el precio de los vehículos, de las materias primas, de la maquinaria agrícola, de los repuestos, de las herramientas, de los insecticidas y, por ende, el valor del transporte, lo que incidiría en la disminución del costo de la agricultura y de la industria. Otro punto central fue la educación. Propuso que el Estado hiciera una inversión sustancial para instruir al pueblo colombiano; según él, la educación debía ser gratuita tanto en la escuela (educación básica primaria) como en el colegio (educación secundaria) y la universidad (Valencia y Jotamario, 1970, p. 73).

El tema de la salud también fue considerado por Rojas Pinilla. Al respecto, pretendía consolidar consultores gratuitos con médicos y odontólogos que pudieran atender especialmente a las clases necesitadas. Asimismo hizo una propuesta de reforma agraria que consistía en otorgar tierras de baldíos nacionales a los campesinos; para cumplir este propósito sostuvo que los latifundios no explotados y los minifundios antieconómicos eran perjudiciales para el país, por lo que se deberían distribuir esas tierras. Y respecto a la solución de vivienda planteó un programa de vivienda propia sin cuota inicial para campesinos, obreros y empleados (Valencia y Jotamario, 1970, p. 44). Sobre la política financiera y fiscal propuso la canalización de todas las

\section{(이요}


políticas a través del Banco de la República con el fin de que este organismo estabilizara y recuperara la moneda. Planteó convertir el crédito en un servicio público con bajo interés. Respecto a la Iglesia, sería el mandatario el encargado de presentar una terna para llenar las vacantes de obispos y arzobispos (Valencia y Jotamario, 1970, p. 45).

En estos puntos expuso situaciones concretas que tenían que ver con los sectores populares que no se solucionaban con el apego al tradicionalismo, ni con la inauguración de obras, sino con el establecimiento de políticas públicas centradas en la problemática de los menos favorecidos. Luego la diferencia en los programas de Rojas y de Pastrana se centró principalmente en la concepción de desarrollo social y económico que necesitaría el Estado colombiano para superar la crisis social; mientras Pastrana defendía el desarrollo económico con el apoyo a las elites económicas, Rojas defendía el bienestar del pueblo y la solución de las necesidades básicas para superar la pobreza.

La campaña electoral se desarrolló entre la movilización de las masas, la publicidad de los medios, las contradicciones de los candidatos, la intervención directa del gobierno en la campaña del candidato oficialista, las denuncias de los seguidores y la crisis social y política que vivía la sociedad colombiana. Es importante resaltar que la socialización de los programas de gobierno generó una agitada participación de las masas, y la participación de las masas fue un aspecto central que usaron los periódicos para resaltar la adhesión a los cuatro candidatos; precisamente en los periódicos se publicaron fotografías donde presentaban cientos de seguidores en las plazas públicas portando banderas, afiches, pancartas e insignias alusivas a los candidatos. Este tipo de reflexiones requiere un análisis sustancial en la medida en que la plaza pública construye, de por sí, un espacio de sociabilidad donde convergen ideas y prácticas que dan cuenta de la articulación de la política con los cambios culturales y sociales, e inciden en la formación de la opinión pública (Irurozqui, 2004).

\section{LOS REGISTROS ELECTORALES EN DISPUTA}

En los comicios de 1970 el sufragio era directo, secreto, y lo podían ejercer todos los ciudadanos mayores de 21 años sin ningún otro requisito, por lo que podríamos inferir que el elector tenía libertad para ejercer ese derecho (Gómez, 1986, p. 128). Durante estas elecciones se pudo apreciar una amplia presencia de los sectores populares en las campañas, lo que obligó a las elites a buscar estrategias para cambiar el número de sufragios a favor de su

\section{()(1) $(9$}


candidato. Se pudo apreciar temor de las elites a perder el control popular y el poder del Estado, y esto llevó al gobierno a implantar tácticas de presión, como el estado de sitio, la censura de la prensa, la detención de los miembros de la Anapo, la vigilancia militar a Rojas Pinilla para evitar ceder el poder a otras tendencias. Como lo señala Marta Irurozqui (2000) "la elite quiso más votantes, pero no más ciudadanos que votasen”; por esto se acudió a la corrupción y a la represión como estrategias centrales para garantizar la permanencia en el gobierno del Frente Nacional.

Los comicios del 19 de abril de 1970 fueron de los más reñidos en la historia electoral colombiana, no entre los tradicionales partidos liberal-conservador, sino ante una nueva fuerza política que había convocado principalmente a los sectores populares a las plazas públicas, atraídos por la expectativa de un programa de gobierno que les ofrecía cambios sustanciales. Por otra parte, las identidades partidistas se habían transformado puesto que, al parecer, los electores eran conscientes de que en las elecciones -además de votar por un partido y por un candidato- le otorgaban legalmente la representatividad al gobernante (Weber, 1944).

En los medios de comunicación se hizo alusión a que el desarrollo de los comicios se había realizado en forma organizada y pacífica, con muy pocas alteraciones del orden público; sin embargo, las controversias se suscitaron en la etapa de conteo y reconteo de los votos. Las ambivalencias en la presentación de los resultados electorales generaron fuertes confusiones en los medios de comunicación y en los electores. Estas versiones, a la vez, se entrecruzaron y generaron polémicas entre el gobierno y los medios, puesto que los electores recibieron comunicaciones que alimentaron la esperanza de triunfo del ex-general Rojas Pinilla como presidente de Colombia; el candidato se pronunció considerándose ganador y prometió hacer un gobierno de paz, justicia y libertad.

A la media noche, en forma intempestiva, fueron desconocidos esos resultados electorales por considerar que "no eran oficiales" (Valencia y Jotamario, 1970, p. 61). Por otra parte, el ministro de Gobierno, Carlos Augusto Noriega, desmintió la información emitida por la radio y cuestionó cualquier tipo de información diferente a la "oficial"; pidió a las emisoras no hacer "telenovela electoral", a la vez que desautorizó las cifras que se habían transmitido; se refirió a estas como improvisadas y no oficiales. ${ }^{9}$ En diversos comunicados se cuestionó la acción del gobierno, especialmente el silencia-

${ }^{9}$ El Siglo, 20 de abril de 1970.

\section{()(1) $\$$}


miento a la radio y la censura impuesta por la transmisión de los resultados electorales. ${ }^{10} \mathrm{La}$ ambivalencia influyó en la forma de percibir el poder expresado por el ministro, que investía una figura de autoridad-dominación racional (Weber) que ponía en duda la información que, hasta ese momento, la opinión pública consideraba oficial.

El 20 de abril, al otro día del debate electoral, los reportajes periodísticos aún eran ambivalentes, pues, según los datos de la Registraduría, Misael Pastrana tenía una pequeña mayoría. La ambivalencia se pudo apreciar en las primeras páginas de los periódicos que presentaron al ganador desde ópticas distintas: El Siglo publicó: "Rojas a la cabecera en cómputos electorales. Amplía su mayoría en centros urbanos", con lo cual le daba el triunfo a Gustavo Rojas Pinilla, aludiendo a los resultados emitidos a las 11 de la noche; periódicos como El Colombiano, La Patria, El País, y otros, también dudaron sobre la publicación de los resultados. En el cuadro 1 se muestran los resultados electorales publicados hasta antes de la medianoche.

Hasta la media noche del 19 de abril el ganador de los comicios presidenciales era Gustavo Rojas Pinilla. Con posterioridad a la emisión de esos resultados se produjeron fallas en el sistema eléctrico en Bogotá que afectaron la transmisión y la consolidación de los resultados; intempestivamente estos empezaron a favorecer a Misael Pastrana Borrero. Estas publicaciones generaron un impacto negativo en los electores que permitió crear una imagen sobre el fraude que, paulatinamente, le dio legitimidad a la participación popular y generó rechazo por las acciones del gobierno; de esta manera los medios de comunicación incidieron en crear opinión pública frente a la corrupción del gobierno en el conteo y reconteo de los votos (Ternavasio, 2003, pp. 62-63).

Los periódicos El Espectador y El Tiempo del 20 de abril publicaron los resultados electorales que daban la mayoría al candidato oficialista, Misael Pastrana, con un total de 1368981 sufragios, frente a 1366364 a favor de Rojas Pinilla. ${ }^{11}$ Según estos resultados ahora el vencedor era Pastrana con aproximadamente 2617 votos de diferencia. Igualmente estos diarios presentaron un informe pormenorizado de los resultados electorales, emitidos por la Registraduría a la media noche, que permitían apreciar el comportamien-

${ }^{10}$ Oficio enviado al presidente Carlos Lleras Restrepo por los trabajadores adscritos a la Federación Nacional de Trabajadores de la Industria de la Construcción, Cemento y Materiales de Construcción. 25 de abril de 1970. Presidencia de la República. Secretaría General. Caja 397, Folios 12-13. AGN, Colombia.

${ }^{11}$ El Espectador, 20 de abril de 1970; El tiempo, 20 de abril de 1970.

\section{()ㅜ(1) $\$$}


Cuadro 1. Resultados electorales a la media noche del 19 de abril de 1970

$\begin{array}{lrrr} & \text { Resultados } & \text { Resultados } & \text { Resultados } \\ \text { Candidato presidencial } & 10: 30 \mathrm{pm} & 11: 45 \mathrm{pm} & 1: 30 \mathrm{am} \\ & & & \\ \text { Belisario Betancur } & 229338 & 353697 & 437218 \\ \text { Misael Pastrana } & 744022 & 1096140 & 1396695 \\ \text { Gustavo Rojas Pinilla } & 753243 & 1117902 & 1429325 \\ \text { Evaristo Sourdís } & 95506 & 157458 & 156544\end{array}$

Fuente: elaborado a partir de la información de El Siglo, 20 de abril de 1970 (11:45 pm); El País, 20 de abril de 1970 (según boletín de prensa de las doce de la noche); La Patria, 20 de abril de 1970 (Boletín de la Registraduría 1:30 am); El Espectador (12:00 pm).

to electoral de la mayoría de los municipios del país. A partir de estos resultados, ambos candidatos reclamaron el triunfo: el uno para dar continuidad al oficialismo y a la institucionalidad, el otro a partir del voto de confianza emitido por los simpatizantes de la ANAPO; de ahí se deriva el cuestionamiento a la legitimidad de las acciones del gobierno.

El 21 de abril de 1970 ya los resultados electorales favorecían a Pastrana por una amplia mayoría; según esto Pastrana había obtenido 1493630 y su contendiente 1471140 ; ya la diferencia era de 22420 votos. Una vez culminada la primera etapa del proceso de conteo se inició la legitimación mediante el uso de la fuerza, la coacción y la beligerancia de la fuerza pública amparada por el gobierno. El planteamiento central aquí no es cómo se efectuó el tipo de fraude que generó reacciones de los electores; el elemento central consiste en analizar los argumentos de la oposición en la denuncia de corrupción y las tesis del gobierno en la legitimación de los resultados.

Sobre el desarrollo de los comicios se generaron diversas pruebas que fueron publicadas por algunos periódicos que no eran partidarios del Frente Nacional: El Siglo, propiedad de Laureano Gómez, líder conservador, opositor del gobierno de Rojas y de tendencias conservadoras, denunció fraude en Arauca y Pamplonita, señalando que se produjo un descenso de los votos de Rojas Pinilla de 2823 a 2 383, mientras que por Pastrana el número ascendió de 2424 a $3096 .^{12}$ También se denunció fraude en Nariño, puesto que el

${ }^{12}$ El Siglo, 1 y 8 de mayo de 1970.

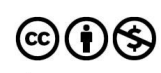


número de papeletas no coincidía con el número de votantes inscritos, otros pliegos no llevaban la firma del registrador; en el departamento de Magdalena se hizo alusión a que había electores que aparecían sufragando sin que sus cédulas se hubieran inscrito; mientras que en Risaralda y Bucaramanga se pudo apreciar la votación de personas fallecidas, los presos comunes, funcionarios del resguardo y otros empleados que, por razones de su posición, se encontraban impedidos para sufragar. ${ }^{13}$

Y sobre la actividad de los jurados de votación, en una comunicación enviada al presidente Carlos Lleras se señaló:

Siendo yo jurado de una de las mesas de votación en mi pueblo Cundinamarqués y que lógicamente se deseaba saber quién sería el vencedor y quiénes los vencidos; pues bien allí ganó a quien usted Sr. Presidente amparara y da garantías para el abuso, Sr. Misael Pastrana jvictoria sobrada sobre los otros candidatos, pero como vieron era uno de los tantos pueblos que corría a las urnas en chocado por el dinero y pareciéndoles poco el triunfo necesitaron poner en el juego mágico de los números el aumento descarado de 1154 a 1554 votos; esto sucedió allí en donde ganaron, pueblo pequeño y fácil de controlar. Qué dirá usted Sr. Presidente de aquellas ciudades donde fue difícil el control y el pueblo no colaboró con su corriente. ${ }^{14}$

Muchas de estas denuncias fueron enviadas al presidente y a los ministros sin que fueran consideradas; se convirtieron en una voz más, mientras el gobierno continuó el proceso de legitimación, tal vez desconociendo la voluntad popular o por lo menos dejando la sensación de que el triunfo de Pastrana se había producido mediante prácticas fraudulentas y poco legítimas. En estos comicios hubo corrupción y violencia política, al igual que en otras elecciones y en otras regiones, como lo plantea Irurozqui (2000) refiriéndose al caso boliviano. En términos generales estas prácticas son consustanciales al proceso electoral y hacen parte de la vida pública y de la expresión política. La característica de este tipo de fraude fue el manejo de la opinión pública que logró poner en evidencia las prácticas corruptas utilizadas por el gobierno, al igual que la coacción y la fuerza para lograr la legitimidad de los resultados (Weber, 1944).

${ }^{13}$ El Siglo, 8 de mayo de 1970.

14 Gasarure, Oficio enviado al Sr. Presidente, Carlos Lleras. Bogotá, 21 de abril de 1970. Presidencia de la República. Secretaría Privada. Caja 109, carpeta 1, f. 5. AgN, Colombia.

\section{()ㅜ(1) $\$$}


Por su parte, los electores vieron que el fraude electoral -considerado legalmente como delito-, había sido utilizado por el gobierno para legalizar los resultados adulterados; así, aunque con el voto se decidía el control del poder de Estado, primaron más las prácticas fraudulentas y violentas que fueron implementadas por los funcionarios del gobierno que representaban la institucionalidad. Por su parte, los líderes de la AnApo instrumentalizaron el discurso de la corrupción a fin de denunciar conductas deshonestas y vicios públicos por parte de la alianza frentenacionalista que deslegitimaba la democracia.

\section{DE LAS URNAS Y EL FRAUDE, A LAS MOVILIZACIONES}

Los resultados electorales paulatinamente favorecían al candidato del oficialismo, mientras los rojaspinillistas marchaban en señal de protesta, a la vez que pronunciaban arengas y reclamaban para sí el triunfo electoral. Muchos de los manifestantes se enfrentaron a la policía con puños, palos y piedras; finalmente se generó un fuerte enfrentamiento con la fuerza pública porque impedía a los manifestantes el acceso a la plaza de Bolívar de Bogotá. La fuerza pública disparó varias granadas, gases lacrimógenos y usó la fuerza para disolver la manifestación. En Bogotá hubo además un desfile militar y de reservistas que estaban a la expectativa para tomar el poder con las armas; sin embargo, no hubo ningún tipo de pronunciamiento por parte de Rojas Pinilla, lo que generó desconcierto en los manifestantes: "En Bogotá todo estaba listo para defender el triunfo, "nosotros teníamos los cañones en la Plaza de Bolívar y no dejó Rojas, no dio la orden”' (citado por Báez, 2006, p. 110).

En el registro electoral publicado el 21 de abril Pastrana Borrero aventajaba a Rojas Pinilla con 50000 votos; este comunicado exaltó los ánimos de los rojistas y empezaron a organizarse para protestar en diferentes zonas de Bogotá y otras ciudades del país, principalmente en los parques y plazas céntricas. En Bogotá, la Plaza de Bolívar fue cerrada al público, entonces los rojistas se reunieron en la avenida Jiménez con Séptima, frente al diario El Tiempo. La movilización enardecida lanzó vivas a Rojas, "abajos" a Pastrana y al gobierno (Serpa, 1999, p. 468). En la medida en que el gobierno pretendía legalizar los resultados fraudulentos, los ciudadanos reaccionaron para reclamar respeto y buscar otras alternativas para acceder al poder; de esta manera el panorama político se transformó, los electores querían vengar la

\section{()(1) $(9$}


burla, pero su líder -el ex general Rojas-, no se pronunció sobre el particular, aunque rechazó el fraude y consideró que las protestas podían ser un medio de denuncia, no fue más allá. Tampoco fue claro su silencio, lo cual generó desconcierto en muchos de sus seguidores, especialmente en líderes como Ignacio-Nacho Vives.

A las once de la mañana se publicó un comunicado por parte de los líderes de la AnApo donde se desconoció el triunfo de Pastrana y se dio como ganador a Gustavo Rojas Pinilla. ${ }^{15}$ Dicho comunicado generó reacciones encontradas: por parte del gobierno se percibió como un movimiento "subversivo" que pretendía derribar el régimen; y respecto a las movilizaciones se dio la esperanza de acceder al poder con la implementación de otras estrategias.

Los manifestantes concentrados en la casa de Rojas Pinilla proponían defender a toda costa el triunfo electoral de la Alianza Nacional Popular; por ejemplo el sacerdote Eugenio Garcés Uribe señaló: "Vamos a defender a sangre y fuego la victoria de la Alianza Nacional Popular." La expresión a "sangre y fuego" significó una convocatoria a la violencia en los años cuarenta, por lo que su pronunciamiento frente a las masas era un motivo de lucha, de incitación a la violencia y posiblemente a la defensa de los derechos del pueblo. A los periodistas del diario El Tiempo les llamó la atención el hecho de que el sacerdote se refiriera a los electores como "amados soldados", y que en sus declaraciones a la prensa internacional planteara que "Colombia necesitaba "una revolución". ${ }^{16}$ Es importante señalar que Garcés era parte de la tendencia más radical de la ANAPO, que promovía el establecimiento del socialismo en Colombia.

Y mientras los manifestantes esperaban una directriz para retomar el poder, en algunos lugares estas movilizaciones culminaron en disturbios. Por ejemplo, en Bogotá apedrearon las instalaciones del rotativo conservador La República, propiedad de Mariano Ospina, la superintendencia bancaria que representaba intereses financieros. Simultáneamente saquearon y semi-

15 "El comando Nacional de la Alianza Nacional Popular declara: Que el gobierno oligárquico que explota Colombia después de haber preparado un escandaloso fraude que está acabando de consumar, que pretende ahora imponer al país un resultado electoral que burla la opinión inequívocamente expresada en las urnas por la abrumadora mayoría nacional.

Que el Presidente electo de Colombia es el General Gustavo Rojas Pinilla.

Que no reconocemos fallo diferente al fallo de esta candidatura, y que estamos tomando medidas necesarias y eficaces para impedir que la oligarquía le robe el poder al pueblo."

Firmado por María Eugenia Rojas, José Ignacio Vives Echeverría, Milton puentes y otros. El Tiempo, 22 de abril de 1970.

${ }^{16}$ El Tiempo, 21 de abril de 1970.

\section{()(1) $\$$}


destruyeron locales comerciales en el centro de Bogotá como imaginario del comercio; igualmente resultaron afectados algunos edificios de San Victorino, entre estos el Banco de la Sabana, el Edificio Colón, y el Chaid Name, que representaban a las elites económicas bogotanas. En Cali, grupos de manifestantes vivaron a Rojas Pinilla y a la ANAPO, lanzaron piedras a almacenes y droguerías; mientras intentaban llegar hasta el palacio de gobierno del departamento del Valle se generaron destrozos en algunos negocios, asimismo fueron apedreadas oficinas de abogados y algunos almacenes; en estas movilizaciones los atentados se hicieron contra los establecimientos económicos y gubernamentales que representaban a las elites económicas y políticas regionales. En respuesta a estos hechos la fuerza pública, especialmente la policía militar, provista de armas y gases lacrimógenos dispersó a los manifestantes, y organismos de la policía nacional bloquearon la sede de la Alianza Nacional Popular con el fin de controlar a los manifestantes; posteriormente se enfrentaron con la fuerza pública. ${ }^{17}$

La marcha rojista efectuada en Santander se organizó en dos etapas: al medio día y a las tres de la tarde. Aquella estuvo dirigida por los sargentos del ejército quienes organizaron un desfile militar por los barrios, hicieron una concentración en el parque de las Mejoras Públicas, hacían bloques de 50; según la entrevista hecha a Jesús Blanco Barón, "Con esa gente llegamos al Parque García Rovira” (citado por Báez, 2006, p. 109). Ya la población se había organizado política y militarmente, solamente esperaba la orden de Rojas Pinilla para defender el triunfo electoral con las armas.

En ciudades como Tunja, Santa Rosa, Barrancabermeja, Sogamoso, Villavicencio y Santa Marta hubo desfiles, movilizaciones, pólvora, pero al parecer no hubo alteración del orden público. En estas poblaciones las manifestaciones se amenizaron con la intervención de oradores de la ANAPo que hicieron fuertes denuncias contra el gobierno. Aunque había muchos seguidores de la ANAPo, en poblaciones como Tunja y Sogamoso era muy fuerte el conservadurismo orientado por Laureano Gómez; el fraude se vivió pero posiblemente no se pretendió defender la legitimidad popular. En Antioquia, grupos de manifestantes de la Alianza Nacional Popular se congregaron y organizaron movilizaciones por las principales calles de la ciudad portando pancartas, banderas anapistas y vivas al ex general Rojas Pinilla. Los manifestantes se concentraron en la sede de la ANAPO, cerca de la gobernación de Antioquia, y posteriormente en la plaza Nutibara. Aunque estas movili-

${ }^{17}$ El Tiempo, 22 de abril de 1970.

\section{()(1) $\$$}


zaciones se hicieron sentir no lograron mayor trascendencia, tal vez porque muchos seguidores apoyaban el triunfo de Belisario Betancur, y porque las elites políticas y económicas no querían el triunfo de Rojas por sus prácticas autoritarias.

En Barranquilla hubo manifestaciones en las áreas comerciales, se rompieron algunos vidrios y resultaron algunos lesionados; los manifestantes portaban cartelones y en sus consignas reivindicaban el triunfo de Rojas. La fuerza pública intervino con gases y presión física hacia los manifestantes; de esta manera, con el uso de la fuerza, se logró el control por parte del gobierno.

En Cartagena los disturbios generados por el choque entre los manifestantes y la fuerza pública impactaron las instalaciones de Telecom, en el edificio de Avianca. La prensa cita un caso de violencia de los manifestantes en María la Baja, donde al parecer intentaron prender fuego al edificio de la Registraduría; asimismo intentaron tomar la estación de policía. En esta ciudad las movilizaciones pretendieron destruir las instituciones que representaban la comunicación y el transporte, así como la institucionalidad representada en la Registraduría y en la Policía.

Las diversas manifestaciones fueron espontáneas, no tuvieron conexión entre sí, por eso en cada localidad tuvieron alcances y pretensiones distintas; aunque muchas de las acciones de protesta pudieron tener mayores alcances, la posición ambivalente de Rojas generó incertidumbre y desconcierto; por otra parte, la fuerza pública logró disolver las manifestaciones con el uso de la fuerza legítima (Weber, 1944).

Ante los disturbios presentados en diversas ciudades del país, el presidente Carlos Lleras Restrepo hizo pública la medida de toque de queda y resaltó que las emisoras estaban censuradas; asimismo advirtió que quienes realizaran manifestaciones o huelgas serían sometidos a la justicia penal militar y al reclutamiento, y serían juzgados por consejo de guerra verbal; igualmente se disolverían las aglomeraciones de más de cinco personas. ${ }^{18}$ Cabe señalar que durante este gobierno se estigmatizó la protesta social y fue asociada con prácticas subversivas, dándole más poder a las fuerzas militares para incidir en la acción de los civiles y "garantizar" la legitimidad del régimen. Al terminar la alocución presidencial comenzaron las detenciones de los líderes de la ANAPo en Bogotá, Barranquilla, Medellín y Cali, especialmente de quienes firmaron el comunicado donde declararon reconocer el

${ }^{18}$ El Tiempo, 22 de abril de 1970.

\section{()(1) $(3$}


triunfo del ex general Rojas. El gobierno - para conservar la institucionalidad y la legitimidad gubernamental-acudió a prácticas autoritarias de violencia y a la coacción contra los manifestantes y opositores al gobierno.

Bajo las nuevas medidas para "garantizar" la democracia, a las doce de la noche el ejército irrumpió en la casa de la ANAPo en la sede de Bogotá y en otras sedes nacionales. En Bogotá el ejército rompió los escritorios, las puertas, las ventanas, tiraron las máquinas de escribir, las carteleras, los afiches de Rojas Pinilla y María Eugenia Rojas. Los manifestantes enardecidos protestaban por el intento de desalojo al que fueron sometidos: en ese momento reaccionaron contra la fuerza pública; con palos y piedras hirieron a varios civiles y militares, mientras la fuerza pública acudió con un escuadrón de caballería y usó gases lacrimógenos para tratar de disolver la manifestación. Los manifestantes, mientras corrían, recogían piedras, latas y palos y los convertían en armas para enfrentar a la fuerza pública.

Después del pronunciamiento del presidente se procedió a clausurar la emisora Radio Latina y el periódico Alerta, propiedad de Rojas Pinilla, por "haber incitado al desorden durante el debate electoral de ayer". ${ }^{19}$ Tampoco el periódico El Siglo circuló; de esta manera se silenció la disidencia y la alusión a las prácticas fraudulentas y, sobre todo, los pronunciamientos de la oposición. Este tipo de estrategias la han utilizado los gobiernos para controlar a la opinión pública y disfrazan en su discurso mecanismos para "garantizar" la democracia; no obstante le temen a la palabra, a la difusión y al impacto de los discursos en la conciencia individual y colectiva.

La detención y aislamiento de los líderes de la ANAPo se realizó en todo el país, como puede apreciarse en las denuncias hechas por sindicalistas y militantes de este partido. Los principales líderes eran: Jaime Piedrahita, Milton Puentes, Manuel Bayona Carrascal y el padre René García (Valencia y Jotamario, 1970, p. 66), fueron conducidos a la prisión militar de Tres Esquinas, en el Amazonas. El presidente Lleras sabía que si las masas no tenían liderazgo abortaría cualquier proyecto político o movilización popular que pretendiera tomar el poder; por ende, la estrategia de encarcelar a los líderes fue evitar el contacto con los simpatizantes, hasta calmar sus ánimos.

Gustavo Rojas Pinilla (candidato de la ANAPO) y su hija también fueron detenidos por el ejército en su propia casa. ${ }^{20} \mathrm{Al}$ respecto Rojas Pinilla refirió que el despliegue militar que rodeaba su casa no era para protegerlo,

19 El Tiempo, 20 de abril de 1970.

${ }^{20}$ El Siglo, 23 de abril de 1970.

\section{(ㅇ)(1) $\$$}


como lo señalaba el periódico El Tiempo, que publicó que el general Rojas y la senadora María Eugenia de Moreno Díaz habían decidido aislarse de las medidas tomadas por el gobierno. "La verdad es que tanto mi hija, como yo, nos encontramos presos" (Valencia y Jotamario, 1970, p. 67).

La crisis del gobierno había llegado a los sectores más radicales, por lo que la presidencia de Pastrana, adicionalmente a la crisis social, debía enfrentar las polémicas por su elección, el cuestionamiento a las prácticas antidemocráticas para legitimar el poder como la detención de líderes anapistas y sindicalistas, ${ }^{21}$ el abuso de autoridad por parte de la fuerza pública, las contradicciones de la política económica y el posicionamiento de los electores frente a la maquinaria gubernamental.

Tres meses después del desarrollo de las elecciones, el 19 de julio de 1970, la Corte Electoral dio a conocer los resultados electorales, que se consideraron oficiales, con lo cual se declaró electo a Misael Pastrana. Por su parte Jorge Villaveces, líder de la ANAPo, dejó una constancia en la cual se refirió al fraude y a la maniobra institucional utilizada para silenciar la verdad; asimismo señaló que el sistema electoral había sido instrumentalizado para generar mecanismos de corrupción y arrebatar los derechos legítimos a la población (Valencia y Jotamario , 1970, pp. 138-139). Con ironía y sarcasmo cuestionó la corrupción y la legitimidad del gobierno que atentaban contra la moral pública, sobre lo cual el pueblo no podía negociar porque esto era un atentado contra la democracia, la ciudadanía y las libertades. El posicionamiento de estos líderes se radicalizó hasta consolidar una tendencia al interior de la ANAPo que se oponía a las prácticas del gobierno y al régimen liberal; según esta tendencia lo que necesitaba la sociedad colombiana era una revolución socialista con un programa nacionalista (León, 2012).

La tendencia radical de la ANAPo pretendía lograr la integración nacional en torno al rechazo del control económico y político de las elites -oligarquías-y de cualquier tipo de intervención imperialista externa, lo que no era ajeno a otras tendencias revolucionarias emergentes en América Latina, entre estas los tupamaros en Uruguay. Estos revolucionarios plantearon la necesidad de ligar la actividad armada con las luchas de masas y adecuarlas a los contextos y particularidades locales. En el caso colombiano, al no ser reconocido el triunfo de Rojas por la vía electoral, se propuso consolidar un

${ }^{21}$ Oficio enviado por los comandos de la Alianza Nacional Popular de los barrios del sur de Bogotá, al presidente Carlos lleras Restrepo, s. f. Legible. Presidencia de la República. Secretaría Privada. Caja 1. Agn, Colombia.

\section{()(1) $(9$}


movimiento de insurrección armada, con el sustento de que el fraude y la violencia siempre los ejercían las elites políticas-oligarcas, y que Rojas Pinilla era una víctima de la demagogia gubernamental; por otra parte, las prácticas de corrupción generadas en los comicios del 19 de abril dejaban la sensación de que el control del Estado no se aseguraba por el triunfo en las elecciones, que era necesario acudir a otro tipo de prácticas y vías de hecho, incluso a la movilización armada.

\section{INCONFORMISMO Y LUCHA POR EL PODER: ENTRE URNAS Y ARMAS}

A pesar de que hubo diversas movilizaciones sociales que protestaban por las irregularidades en el conteo y reconteo de los votos, durante los tres años siguientes al desarrollo de los comicios no se consolidó un movimiento armado en señal de protesta, tal vez porque Rojas Pinilla actuó con indecisión, porque la detención de los líderes políticos de la ANAPO impidió un tipo de organización, o porque las excesivas medidas de presión y coacción asumidas por el gobierno impidieron las movilizaciones populares y el pronunciamiento de simpatizantes de la AnAPO.

Después del reconteo de los votos y de la expedición de la credencial que le dio el triunfo a Pastrana, se generó incertidumbre en los seguidores de la ANAPO, por lo que se consolidaron dos tendencias: la tendencia del ala derechista de la ANAPo propuso la consolidación de un tercer partido, desligado del liberalismo y del conservadurismo; esta fue la razón de la movilización de 100000 personas en la plaza de Villa de Leyva, el 13 de junio de 1971. Esta tercera fuerza mantendría los postulados de un partido nacionalista, revolucionario popular, con un sentido socialista y populista. Este partido fundamentó su lucha en tres postulados esenciales: defensa de la soberanía patria; aplicación del socialismo dentro de las condiciones y características del país, y afirmación de que el hombre como ser humano debía construir la principal preocupación del Estado (Serpa, 1999, p. 276). Estos postulados fueron retomados del movimiento anapista en el sentido de integrar al pueblo liberal y conservador para llegar al poder, y desde allí hacer la revolución cristiana y nacionalista que Colombia necesitaba. ${ }^{22}$

${ }^{22}$ Gustavo Rojas Pinilla, comunicado número 4, sobre el memorándum enviado a los candidatos presidenciales por el doctor Carlos Lleras Restrepo. Presidencia de la República.

\section{()(1) $(9$}


El ala izquierda de la ANAPo planteó consolidar un movimiento armado para emprender la revolución socialista, aunque la pretensión era tomar el poder con las armas y con el apoyo de las masas. Los simpatizantes de esta tendencia eran líderes de la Juventud Comunista (Juco), que militaban en las FARC, pero quienes veían igualmente que al interior de esa guerrilla se deberían dar cambios sustanciales, como la militancia en el área urbana y un mayor despliegue ideológico y militar. Al respecto Jaime Bateman, uno de los fundadores de la guerrilla del M-19, señaló: "cuando estábamos en las FARC vimos que si no introducíamos cambios en la forma de lucha el triunfo jamás se produciría"; según esta tendencia la lucha había que llevarla "a donde más les duela" (Lara, 1982), es decir, a los centros urbanos y de producción. Según estos líderes se debería combinar la guerrilla rural con la guerrilla urbana. Dentro de las FARC este tipo de propuesta no fue bien vista, por lo que fueron expulsados Jaime Bateman, Álvaro Fayad, Iván Marino Ospina y Luis Otero.

Por otra parte, los resultados electorales de abril de 1972 evidenciaron un debilitamiento electoral de la ANAPO, que daba cuenta de una fuerte crisis. Al respecto, César Ayala (2005, p. 24) señala que la crisis de la AnAPo se debió a las controversias entre sus miembros relacionadas con la orientación que debería seguir el movimiento.

Para la época se perfilaban varias tendencias que se desligaban de la ANAPO y que proyectaban la consolidación de movimientos políticos con perspectivas nacionalista, socialista y otras que consideraban la posibilidad de un movimiento armado. Por ejemplo, entre 1970 y 1972 el grupo expulsado de las FARC, encabezado por Jaime Bateman, consolidó un proyecto de guerrilla urbana con el nombre de comuneros. Bateman inició un proceso de incorporación de jóvenes expulsados e inconformes con otras tendencias guerrilleras y con la pretensión de realizar la revolución social que el país necesitaba para derribar definitivamente a las oligarquías (León, 2012, pp. 239-259).

$\mathrm{Al}$ ser expulsados de las FARC Jaime Bateman y otros líderes, consolidaron una organización nacionalista, popular y revolucionaria, con el fin de hacer que se respetaran los derechos del pueblo colombiano. Así nació la propuesta de guerrilla urbana denominada Movimiento 19 de Abril. Otra etapa fue la articulación con la ANAPO, que tenía la experiencia política y se había convertido en un movimiento de masas encabezado por Carlos Toledo Plata, Andrés Almarales y María Eugenia Rojas. Sin embargo, el

30 de abril de 1970. Presidencia de la República. Secretaría Privada. Caja 89, exp. 1. AGN, Colombia.

\section{(ㅇ)(1) $\$$}


punto de articulación fue la denuncia de fraude electoral, precisamente en la carta que envió la tendencia armada M-19 a María Eugenia Rojas (líder política de la ANAPo) en mayo de 1974 señalando: "Hemos comprobado, una vez más, que las elecciones eran el mejor mecanismo que tenía la burguesía colombiana para prolongar su régimen de privilegios y que, mientras él imperara, emplearíamos todas las formas de lucha hasta llegar a aniquilarlo" (Lara, 1982). De esta manera se hizo alusión a un movimiento político-militar que defendería los intereses políticos de los colombianos, cuyo lema fue: "iCon el pueblo, con las armas, con María Eugenia, al poder!" Este movimiento tendría un brazo amparado en un movimiento político, es decir la ANAPO, que seguiría insistiendo en obtener el poder por la vía electoral, y el brazo armado como componente central de la lucha revolucionaria.

A comienzos de 1974 aparecieron los primeros avisos publicitarios que hacían alusión al M-19; estos se publicaron en cines, en páginas interiores, clasificados y páginas sociales, tenían un fondo negro y en letras blancas se leía: "Ya llega M-19", "Parásitos... gusanos? Espere M-19", "Decaimiento... falta de memoria? Espere M-19", "Falta de energía... inactividad? Espere M-19". $\mathrm{Y}$ al lado de las siglas M-19 dos triangulitos que daban la apariencia de corbatín, como se puede apreciar en las imágenes 1-3.

El día 17 de enero de 1974 apareció el último aviso: "Hoy llega M-19". ${ }^{23}$ Sumado a los avisos publicitarios, la organización político-militar sustrajo la espada de Bolívar y de esta manera lo convirtió en el icono de la revolución, y en su proclama señalaron: "Bolívar, tu espada vuelve a la lucha". Junto a la proclama colocaron el logotipo que había salido en varios periódicos durante los últimos días, es decir, los dos triangulitos en forma de corbatín y la sigla M-19. ${ }^{24}$ Estos dos símbolos -tanto el iconográfico como el robo de la espada de Bolívar- se convertirían en la forma de difusión y presentación de un nuevo movimiento político-militar que, con las armas, pretendería defender la democracia, con un programa nacionalista bajo una perspectiva de revolución socialista.

Entre diciembre de 1973 y enero de 1974 se fundó y lanzó el M-19; los símbolos escogidos para representar a la nueva guerrilla ante la sociedad formaron una combinación completamente ambigua, que adoptó el apoyo

${ }^{23}$ D. Villamizar Herrera, Recuerdos del Eme. Revista Semana, 1 de enero de 1996.

${ }^{24}$ D. Villamizar Herrera, Recuerdos del Eme. Revista Semana, 1 de enero de 1996.

\section{(ㅇ)(1) $\$$}



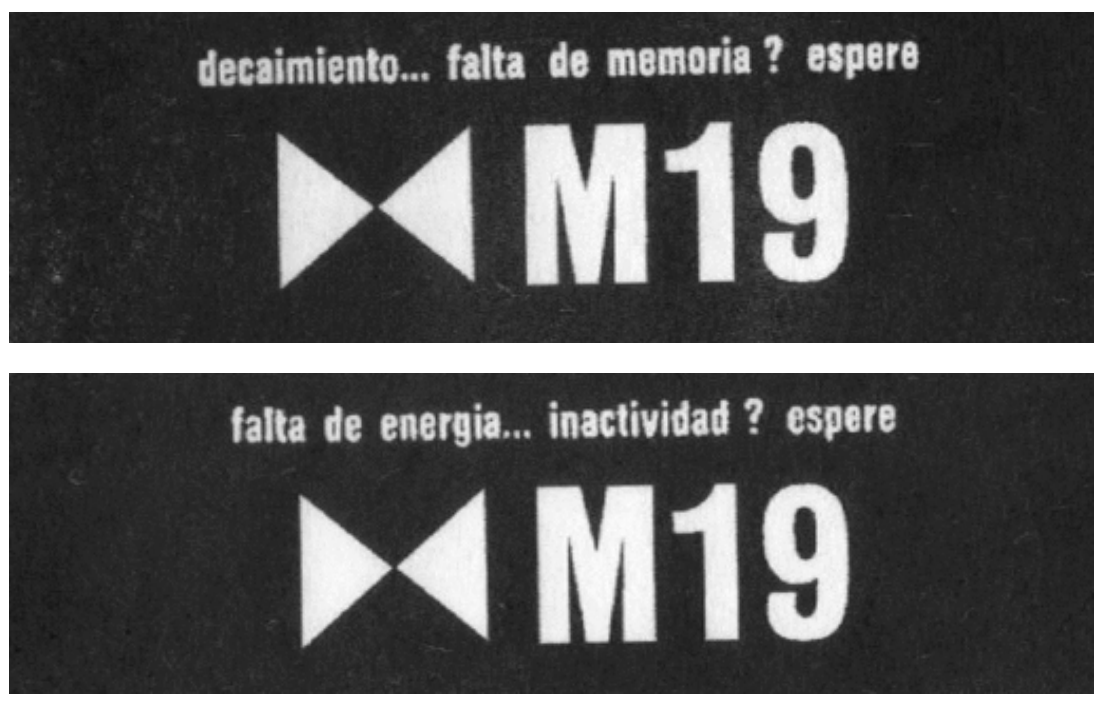

\section{parásitos... gusanos? espere}

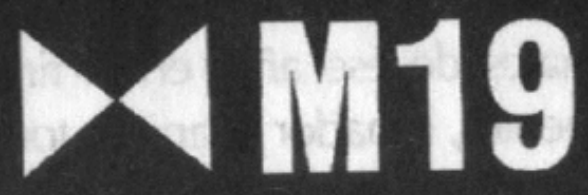

Imágenes 1-3. Avisos publicitarios del M-19.

Fuente: Enrique Santos Calderón, Testimonio Histórico M-19; iAsí Los Vieron!, consultado el 8 de marzo de 2014.

con las armas en las decisiones electorales del pueblo anapista, aludiendo al fraude electoral cometido contra el candidato Gustavo Rojas Pinilla en las elecciones de 1970, en las cuales el debate central fue la legalidad o la ilegalidad. Esta nueva corriente acogió los colores azul, blanco y rojo; colores de la bandera de la AnAPO. Asimismo asumieron la reivindicación de Bolívar que a la larga se convertiría en un símbolo ambivalente (León, 2012).

Por otra parte, los objetivos perseguidos por ambas tendencias eran ambiguos: por un lado se defendía la democracia y la institucionalidad, y por el otro, la movilización armada articulada con una movilización de las

\section{()(1) $(2)$}


masas. La diferencia y polarización de las tendencias se pudo apreciar en los intereses perseguidos; por ejemplo, las pretensiones de Rojas Pinilla y de su hija María Eugenia no encajaban en una revolución social, ellos simplemente buscaban ser parte de las oligarquías, por eso Rojas nunca asumió una oposición radical en contra del gobierno, en relación con el fraude electoral y a las medidas autoritarias de Carlos Lleras. Mientras tanto, la tendencia más radical de la ANAPO pretendía abolir las oligarquías y cualquier tipo de intervención extranjera.

Según Navarro Wolff, el M-19 rompió con todos los esquemas tradicionales de la izquierda en Colombia, pues en ese momento dichas organizaciones estaban orientadas por proyectos políticos internacionales, pero la colombianidad no aparecía por ninguna parte; por lo tanto se acudió a la ANAPo, que era un movimiento de masas cercano al populismo, inspirado en el fraude electoral del 19 de abril de 1970 y en la reivindicación del nacionalismo. Así se consolidó un proyecto con características propias; en ese sentido se empezó a ver que la democracia era un proyecto revolucionario. Posteriormente se usaron los textos de Bolívar para tratar de entender su perspectiva revolucionaria, y de esa manera se vio en Bolívar un proyecto latinoamericano y antiimperialista (estadunidense) (Jiménez, 1986, pp. 82-104).

\section{CONCLUSIONES}

A lo largo de este texto no nos hemos preguntado por el fraude como práctica consustancial al sistema democrático, implementado de diversas maneras y legitimado con prácticas de presión y coacción. Hemos querido dar respuesta a la disputa por el poder político, a la forma como los electores asumen su papel como ciudadanos desde ópticas distintas, no solamente en el ejercicio de emitir su voto, sino en definir y articular su papel político. Por otra parte, hemos podido apreciar el juego y la ambivalencia desplegados por los grupos involucrados en los procesos electorales para incidir en la voluntad popular en las tres etapas del proceso electoral, pre-durante-y poselectoral; lo anterior nos acerca al funcionamiento del sistema político, donde se ponen en juego diversos escenarios: las relaciones Estado-sociedad; la democracia y la ciudadanía; la formación de la opinión pública, y el control del poder a través de las redes que se generaron.

Las elecciones presidenciales de 1970 están asociadas con uno de los mayores fraudes en la historia electoral colombiana, porque se acudió al

\section{(이요 $(3$}


poder, a la ambivalencia y al uso de la fuerza para legitimar los resultados electorales. Los colombianos fueron conscientes de que los mecanismos fraudulentos eran consustanciales a la democracia, pero la memoria de los electores se fijó en el conteo y reconteo de los votos, en el papel de personajes como el ministro de Gobierno, Carlos Noriega, al desmentir los resultados transmitidos por la radio y con los nuevos resultados cambiar el rumbo de las estadísticas electorales.

En los comicios de 1970 se concentró una polémica sustancial que osciló entre el desarrollo y las medidas para combatir la pobreza. Dichos debates lograron replantear las tendencias políticas y motivaron a los electores a seguir un programa de gobierno con miras a solucionar los problemas de primera necesidad en los sectores populares de la sociedad colombiana.

Aunque la legitimación de las elecciones generó reacciones encontradas en las cuales se pudo apreciar la articulación, odios, resentimientos y contradicciones que llevaron a los electores a protestar, movilizarse, organizar un tercer partido y conformar una organización armada, guerrilla urbana, bajo la denominación de M-19.

Las elecciones fueron el medio de legitimación para acceder al poder. Los cuatro candidatos tuvieron la posibilidad de presentar sus programas y buscar la participación popular. Asimismo los electores tuvieron la posibilidad de elegir "libremente" a uno de los candidatos; por lo tanto, la competitividad fue una de las características de las elecciones de 1970, porque permitió a otras tendencias políticas, diferentes al Frente Nacional, presentar candidatos presidenciales. Sin embargo, la competencia era desigual porque no todos contaban con los mismos recursos económicos, institucionales y apoyos de líderes políticos para realizar sus campañas. Por ejemplo, el candidato oficialista Misael Pastrana contó con el apoyo de los medios de comunicación de circulación nacional; se dispusieron apoyos físicos y financieros para la respectiva publicidad. Adicionalmente el presidente Carlos Lleras y el alcalde de Bogotá, Virgilio Barco, que investían una figura de autoridad, acompañaron a los electores y les dieron instrucciones.

Aunque había inconformismo frente al gobierno de las elites políticas y económicas, expresado en la continuidad del control del gobierno del Frente Nacional que tendía a consolidar un partido único en Colombia, el detonante fue el cuestionamiento a la legitimidad de los resultados electorales, lo cual suscitó fuertes pronunciamientos de los seguidores y militantes de la Anapo, quienes reclamaban el triunfo de Rojas Pinilla, su caudillo. Con estas expresiones de inconformismo expresadas a través de comunica-

\section{()(1) $(9$}


dos, manifestaciones, movilizaciones y tres años después la consolidación de un movimiento armado, además de defender la democracia del pueblo colombiano, se proponía hacer la revolución social, que además de manifestarse en contra de la dominación de las oligarquías y del sistema económico, promovieron el establecimiento del socialismo en Colombia; de esta manera justificaron el movimiento armado.

El fundamento central estaba en "lo que se disputaba en las urnas", la continuidad del poder de las elites representada en el candidato del Frente Nacional, Misael Pastrana; adicionalmente un proyecto económico que promovería el desarrollo, a partir de la tecnologización y la industrialización, que generó desconcierto en ciertos sectores sociales.

Finalmente, para legitimar el poder -a partir de los resultados electorales que le darían legitimidad al gobierno-, este acudió a la implementación de prácticas dictatoriales como la censura a los medios, el uso de la fuerza y la coacción en contra de los manifestantes, así como a la persecución y detención de líderes de la oposición. De esta manera también se pudo apreciar una contradicción en el uso del poder, puesto que en los discursos de campaña el gobierno frentenacionalista se declaró defensor de la democracia y rechazó el autoritarismo, al que asoció con la candidatura de Gustavo Rojas Pinilla, líder de la Alianza Nacional Popular. Desde esta perspectiva se pudo apreciar cómo el uso del poder, en su búsqueda de legitimidad, afianzó las diferencias entre las tendencias políticas que protestaban por el usufructo del poder por parte de las maquinarias tradicionales, por la falta de políticas sociales, a la vez que reclamaban respeto por sus derechos.

\section{LISTA DE REFERENCIAS}

Acuña Rodríguez, O. Y. (2010). Construcción de ciudadanía en Boyacá durante la República Liberal 1930-1946. Tunja: uptc.

Annino, A. (comp.) (1995). Historia de las elecciones en Iberoamérica siglo XIX. Buenos Aires: FCE.

Ayala Diago, C. A. (2005). La variante colombiana del populismo o la Alianza Nacional Popular (AnAPo) como síntesis. Ponencia presentada en el IV Congreso de la Asociación de Colombianistas. Colombia: Tiempos de Imaginación y Desafío. Denison University, Granville, Ohio. Recuperado de http://www.colombianistas.org/Portals/0/ Congresos/Documentos/CongresoXIV/PonenciasPDF/ayala_diago_ponencia.pdf

\section{()(1) $\$$}


Ayala Diago, C. A. (2006). El populismo atrapado, la memoria y el miedo. El caso de las elecciones de 1970. Medellín: La Carreta Editores.

Báez Pimiento, A. (2006). La Alianza Nacional Popular (ANAPO) en Santander 19621976 (Tesis de maestría inédita). Universidad Industrial de Santander, Colombia.

Bushnell, D. (febrero de 1994). Las elecciones en Colombia: S. xix para bien o para mal, las elecciones han sido una característica nacional. Revista Credencial de Historia, 50. Bogotá.

Gómez Tagle, S. (1986). Democracia y poder en México: el significado de los fraudes electorales en 1979, 1982 y 1985. Revista Nueva Antropología, Ix(31). Recuperado de http://www.redalyc.org/pdf/159/15903106.pdf

González Calleja, E. (2003). La violencia en la política. Perspectivas teóricas sobre el empleo deliberado de la fuerza en los conflictos de poder (632 pp.). Madrid: Consejo Superior de Investigaciones Científicas.

Irurozqui Victoriano, M. (2000). A bala, piedra y palo. La construcción de la ciudadanía política en Bolivia. 1826-1852. Sevilla: Diputación de Sevilla.

Irurozqui Victoriano, M. (2004). La ciudadanía en debate en América Latina. Discusiones historiográficas y una propuesta teórica sobre el valor público de la infracción electoral. Documento de trabajo, 139. Instituto de Estudios Peruanos (serie Historia 6). Recuperado de: http://lanic.utexas.edu/project/laoap/iep/ddt139.pdf Jiménez Ricárdez, R. (enero-marzo de 1986). Entrevista a Antonio Navarro Wolff/M-19: Paz y guerra en Colombia. Cuadernos Políticos, 45.

Lara, P. (1982). Entrevista a Jaime Bateman. En P. Lara, Siembra vientos y recogerás tempestades. México: Editorial Planeta. Recuperado de http://www.siporcuba.it/ Jaime\%20Bateman\%20Profeta\%20de\%20la\%20paz.pdf

Lehoucq, F. (2007). ¿Qué es el fraude electoral? Su naturaleza, sus causas y consecuencias. Revista Mexicana de Sociología, 69.

León Palacios, P. C. (julio-diciembre de 2012). La ambivalente relación entre M-19 y AnApo. Anuario Colombiano de Historia Social y Cultura, 39(2).

Luna Benítez, M. (abril de 2006). El M-19 en el contexto de las guerrillas colombianas. Revista Sociedad y Economía, 10, 157-188. Recuperado de http://sociedadyeco nomia.univalle.edu.co/index.php/sye/issue/view/33

Malamud, C. (comp.) (2000). La legitimidad, representación y alternancia en España y América Latina: las reformas electorales (1880-1930). México: FCE/El Colegio de México.

Narváez Jaimes, G. E. (2012). La guerra revolucionaria del M-19 (1974-1989) (Tesis de maestría). Universidad Nacional de Colombia, Colombia.

Nohlen, D. (1995). Elecciones y sistemas electorales. Caracas: Fundación Friedrich Erbert Nueva Sociedad.

\section{()(1) $\$$}


Posada Carbó, E. (2000). Fraude al sufragio: la reforma electoral en Colombia 1830-1930.

En C. Malamud (comp.), Legitimidad, representación y alternancia en España y América Latina: las reformas electorales (1880-1930). México: FCE/El Colegio de México.

Posada Carbó, E. (2003). Elecciones y guerras civiles en la Colombia del siglo xix: la campaña presidencial de 1875. En E. Posada Carbó, El desafío de las ideas. Ensayos de historia intelectual y política en Colombia. Medellín: Fondo Editorial Universidad EAFIT.

Pozzi, P. A. y Pérez, C. (eds.). (2011). Por el camino del Che. Las guerrillas latinoamericanas 1959-1990 (p. XIII). Buenos Aires: Immago Mundi.

Sábato, H. (1998). La política en las calles. Entre el voto y la movilización. Buenos Aires 1862-1880. Buenos Aires: Editorial Sudamericana.

Serpa Eraso, J. (1999). Rojas Pinilla una historia del siglo xx. Bogotá: Planeta Colombiana.

Ternavasio, M. (2002). La revolución del voto. Política y elecciones en Buenos Aires, 18101852. Buenos Aires: Siglo XXI.

Ternavasio, M. (2003). La visibilidad y el consenso. Representaciones en torno al sufragio en la primera mitad del siglo xix. En H. Sábato y A. Lettieri, La vida política en la Argentina del siglo XIX. Además, votos y voces. Buenos Aires: FCE.

Valencia, E. y Jotamario (agosto de 1970). Libro Rojo de Rojas. Bogotá: Ediciones Culturales.

Weber, M. (1944). Economía y sociedad (vols. I y II). México: FCE.

Weber, M. (2000). El político y el científico. México: Ediciones Coyoacán.

\section{OTRAS FUENTES}

Archivo

AGN Archivo General de la Nación, Colombia.

\section{Hemerografía}

El Espectador

El País, Cali.

El Siglo, Bogotá.

El Tiempo

La Patria, Manizales.

Revista Semana, Bogotá. 


\section{Bibliografía}

Acuña Rodríguez, O. Y. (2007). Ciudadanía y prácticas electorales. Cali: Universidad del Valle.

Acuña Rodríguez, O. Y. (2010). Elecciones y poder político en Boyacá 1930-1950. Cali: Universidad del Valle.

Gantús, F. (mayo de 2012). Caricatura y prensa. Una reflexión en torno a las imágenes y su importancia en la investigación histórica. El caso mexicano, siglos XIX-XX (pp. 73-88). Domínios da Imagem, v(10). Londrina. DoI: http://dx.doi.org/10.5433/ 2237-9126.2012v6n10p73

Posada Carbó, E. (2003). Malabarismos electorales: una historia comparativa de la corrupción del sufragio en América Latina, 1830-1930. En El desafío de las ideas. Ensayos de historia intelectual y política en Colombia. Medellín: Fondo Editorial Universidad EAFIT. 